\title{
What Do We Know About The Variance Of Audit Quality? An Empirical Study From The Perspective Of Individual Auditor
}

Baolei Qi, Xi'an Jiaotong University, P.R. China

Bin Li, Xi'an Jiaotong University, P.R. China

Gaoliang Tian, Xi'an Jiaotong University, P.R. China

\begin{abstract}
In this paper, we analyze the variance in audit quality among a broad cross-section of listed firms in Chinese stock market from 1999 to 2012. The purpose of the analysis is to identify the importance of audit firm, audit client, and engagement auditor effects on the variance in audit quality. Using discretionary accruals and financial restatement to surrogate audit quality and based on simultaneous ANOVA method, we find that engagement auditor can add about $19 \%$ of incremental explanatory power to the variance in audit quality. As expected, audit firm effects and audit client effects also have significant influence on audit quality, which can add about $2 \%$ and $16 \%$ of incremental explanatory power to the variance in audit quality. In addition, we find that, relative to engagement auditors with short audit experience, engagement auditors with longer audit experience have no significant incremental power in explaining variance in audit quality. The analysis enriches previous studies by investigating audit client's role and engagement auditor's role in determining audit quality. Our study highlights the importance of understanding audit quality from the perspective of individual auditor.
\end{abstract}

Keywords: Individual Auditor; Audit Quality; Audit Client; Audit Tenure

\section{INTRODUCTION}

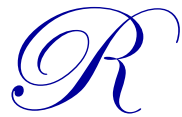

egulators, policy makers, investors, and researchers in accounting field have long been interested in understanding the determinants of audit quality. What do we know till now about the variance of audit quality? In the U.K., the Financial Reporting Council (FRC) has articulated a framework for audit quality that identifies five drivers of audit quality: the culture within an audit firm, skills and personal qualities of engagement auditors, effectiveness of the audit process, reliability and usefulness of audit reporting, and factors outside the control of auditors such as corporate governance, audit committees, and shareholders support of auditors (FRC, 2006). Francis (2011) presents similar framework for understanding and researching in audit quality, in which he states:

"Audits are of higher quality at the input level when the people implementing audit tests are competent and independent, and when the testing procedures used are capable of producing reliable and relevant evidence. The quality of audit inputs flow through to the audit process, where audits are of high quality when the engagement team personnel make good decisions regarding the specific tests to be implemented and appropriately evaluate the evidence from these tests in leading to the audit report. Audit quality is affected by the accounting firm in which the auditors work. Firms develop the testing procedures used on audit engagements, and create incentives that affect the behavior of engagement team personnel. Last, the incentives of accounting firms and individual auditors to produce high-quality audits are affected by the institutions that regulate auditing and punish auditors and accounting firms for misconduct and low-quality audits". 
FRC (2006) and Francis (2011) both emphasize the importance of audit client, accounting firm, and engagement auditor in determining audit quality. However, prior researches more incline to focus on audit firm's role in determining audit quality, and a large number of empirical literature has provided valuable insights from the perspective of audit firm-level (Palmrose 1988; Becker et al. 1998; Lennox 1999; Francis et al. 1999; Reynolds and Francis 2000; Khurana and Raman 2004; Behn et al. 2008; Francis 2011; Francis and Michas 2013), audit officelevel (Reynolds and Francis 2000; Francis and Yu 2009; Li 2009; Choi et al. 2010), and accounting firm industry expertise (Krishnan 2003; Ferguson et al. 2003; Francis et al. 2005; Reichelt and Wang 2010). So far, besides lately empirical studies on partners tenure (Carey and Simnett 2006; Chen et al. 2008; Wang et al. 2012), little research tries to explore the role of audit clients and engagement auditors in determining audit quality. Do the audit clients and engagement auditors really matter to audit quality?

The research on this question is very important for several reasons. First, the association between audit clients and audit quality expand our knowledge about whether and how audit clients influence audit quality. Financial statements are jointly produced by clients and their engagement auditors (Antle and Nalebuff 1991; Nelson et al. 2002; Gibbins et al. 2010), and large clients create economic dependence that may cause auditors to compromise their independence (Reynolds and Francis 2000). Engagement auditors need to collect sufficient competent evidence before issuing audit reports. However, the difficulty of collecting sufficient competent audit evidence varies among different audit clients. In addition, the financial conditions, audit risks, and audit complexities also vary among audit clients, and these factors have been documented having the power to influence audit quality. Lawrence et al. (2011) articulate that differences in audit quality between Big 4 and non-Big 4 firms may largely reflect client characteristics, so they encourage other scholars to explore alternative methodologies that separate client characteristics from audit-quality effects. In this research, we contribute to the literature by comparing the relative incremental explaining power of audit client effects in the determination of audit quality with several other effects.

Second, the relation between engagement auditors and audit quality expand our knowledge about whether and how engagement auditor influences audit quality. Auditing process is "primarily human endeavors and audit firms are very dependent upon the quality of their professionals, including competence and decision-making skills" (Prawitt et al. 2009) ${ }^{1}$. Many scholars call for research on engagement auditors' role in the determination of audit quality. Nelson and Tan (2005) call for more attention to individual auditor characteristics in the design of judgment decision-making research, and Hurtt (2010) develops a measure of an individual auditor's capacity for professional skepticism. Francis (2011) argues that auditors' knowledge of auditing theory/standards is critical to audit quality and the audits are of higher quality when undertaken by competent auditors. Surprisingly, little empirical research has been done on this topic in the past 20 years, and we still know very little about the engagement auditor's role in the determination of audit quality and why it is important.

Third, researching on the relation between engagement auditors and audit quality can provide evidence to the current policy debate on engagement auditor identification. As we discussed in prior section, individual engagement auditor has the potential to influence audit quality, disclosing individual engagement auditors' name on audit report may convey useful information to shareholders with regard to audit and the quality of financial report. Considering this reasoning, the Public Accounting Oversight Board (hereafter the PCAOB) issued "Concept Release on Requiring the Engagement Partner to Sign the Audit Report" (hereafter Concept) on July 28, 2009, proposing to mandate the engagement auditors to sign their name on the audit report in addition to the existing requirement for the firm to sign the audit report. There are two key issues concerned about the Concept: (1) whether audit quality varies with individual engagement auditor in addition to firm level characteristics ${ }^{2}$ ? (2) Whether engagement auditors' individual characteristics convey information useful to shareholders with regard to audit quality? To our best knowledge, little empirical evidence exists for the above questions and the PCAOB calls for research investigating these issues (PCAOB 2009, page 9).

\footnotetext{
${ }^{1}$ DeFond and Francis (2005) suggests pushing the analysis to individual level, if possible, because determinants of audit quality should be more significant at individual level.

${ }^{2}$ In the Concept, the PCAOB states "Providing financial statement users, audit committees, and others with the name of the engagement partner might help them evaluate the extent of an engagement partner's experience on a particular type of audit and, to a degree, his or her track record." (PCAOB 2009, page8-9).
} 
In this research, based on the approach used in McGahan and Porter (2002), we decompose the variance of audit quality into components associated with audit client, audit firm, and engagement auditor ${ }^{3}$. Prior studies related to audit quality incorporated the assumption that audit firm or audit office shaped auditor's characteristics, which in turn drive audit quality. This assumption implicitly ruled out alternative directions of causality. No provisions were made for the possibility that audit quality is driven by engagement auditor or engagement auditor influences the quality of audit firm or audit office. Following McGahan and Porter (2002), we employ a simultaneous ANOVA implemented using regression analysis ${ }^{4}$. The simultaneous ANOVA allows for a full set of covariance effects but does not assume randomness in the model errors. This study departs from much of the cross-sectional literature by being fundamentally concerned with the importance of audit firm effects, audit client effects, and engagement auditor effects, not just with coefficient signs and t-statistics.

We investigate the research questions based on the audit data from Chinese stock market, where engagement auditors are required to sign their name on the audit reports 5 . Following prior studies, we use absolute discretionary accruals and financial restatement as the proxies of low audit quality (Becker et al. 1998; Francis et al. 1999; Carey and Simnett 2006; Francis and Yu 2009; Francis 2011; Francis et al. 2013). Using the data from 1999 to 2012, we find that, as documented before, audit firm is one of the most important factors in the determination of audit quality, which is indicated by it accounts for about $2 \%$ of the explanation power of audit quality. We find that audit client accounts for about $16 \%$ of the explanation power of audit quality, and engagement auditor accounts for about $19 \%$ of the explanation power of audit quality. It is the first time to find the audit client and engagement auditor has incremental explanation power in the determination of audit quality using empirical analysis based on large sample.

Several studies began to concern about the effect of engagement auditor tenure or audit experience on audit quality (Carey and Simnett 2006; Chen et al. 2008; Wang et al. 2012). They have not drawn consistent conclusions about the association between engagement auditor tenure (audit experience) and audit quality. We measure the audit experience as the number of years the engagement auditor began his or her career as an auditor, and then we further divide the audit experience into general audit experience and client-specific audit experience. However, we find no evidence that the engagement auditors who have longer general or client-specific audit experience have significant higher incremental explanation power in the determination of audit quality.

We note that some caveats may compound the results we find in this paper. First, the analysis is based the data come from Chinese stock market, where the regulations on capital market and audit practice are different from the developed markets, such as U.S., U.K., Australia etc., which limits the generalizability of our results. Further research should try to investigate the variance of audit quality based on cross-country data. Second, the variables we used as proxies of audit quality also may compound the results we find in this paper. We use absolute discretionary accruals and financial restatement as the proxies of audit quality. Although most of the prior studies use these variables as the proxies of audit quality and have documented that these variables can reflect audit quality on some extent, however, these variables are still not the direct measure of audit quality ${ }^{6}$. Francis (2011) argues that engagement-level audit failures can be unambiguously identified when there is successful civil litigation against auditors or audit firms. We use proxies instead of direct measure because the successful civil litigations against auditors or audit firms are very rare during our research interval. Further study should use the direct measure of audit quality if they can get enough data.

Besides the caveats we discussed above, this research contributes to the literature in the following ways. First, this research may help regulators, policy makers, investors, and accounting scholars to better understand the

\footnotetext{
${ }^{3}$ McGahan and Porter (2002) employ a simultaneous ANOVA implemented using regression analysis. They decompose the accounting profitability across business segments into the components associated with industry, corporate-parent, and business-specific.

${ }^{4}$ We do not use components-of-variance (COV) and nested ANOVA because: the COV approach requires the assumption that each of the effects on a particular firm is drawn independently of the others and the nested ANOVA approach does not model covariance between effects. The strong covariance between audit firm and engagement auditor effects suggests flaws in the assumptions required under both approaches.

${ }^{5}$ The China Certified Public Accountants Auditing Standards (CCPAAS) No.7-Audit report $(1996,2003)$ stipulates that the two engagement auditors must sign their name on the audit report.

${ }^{6}$ Francis (2011) define audit failure as "an audit failure occurs if the auditor is not independent in fact, or if an independent auditor incorrectly issues a clean audit report due to the failure to collect sufficient competent evidence as required by auditing standards". And Francis (2011) also admits that the extant evidence indicates there are relatively few demonstrable audit failures.
} 
multiple drivers of audit quality. The results of this paper indicate that in addition to audit firms, audit clients and engagement auditors also have significant incremental explanation power in the determination of audit quality. Second, our research is the first paper to decompose variance of audit quality into components relates to audit firm, audit client, and engagement auditor, respectively. This research design enables us to estimate the effects of each part separately and makes the effects of each part comparable. Third, the results we find in this research provide direct evidence to the policy debate on mandatory engagement auditor identification. The results indicate that engagement auditor accounts for about $19 \%$ of incremental explanatory power in the determination of audit quality, which is highest among all the factors. That is to say, engagement auditor is the most important factor in the determination of audit quality. The results of this research also have some implications for policy makers and audit firms. Given the importance of engagement auditor in the determination of audit quality, policy makers (e.g. AICPA) should pay more attention to the procedures that enable a person to get his/her CPA certification. Audit firms should pay more attention to the skills and ethic level when hiring auditors, and audit firms also should care more about their training procedures.

The rest of the paper is organized as follows: we review the literature in Section 2; Section 3 explains the methods we employed in this research, the data and sample used in this research are also introduced in this section. Section 4 displays the empirical results. Section 5 presents the robust tests. Section 6 consists of some additional tests. Section 7 concludes.

\section{LITERATURE REVIEW}

Francis (2011) proposes a framework for understanding and researching in audit quality, in which he points out that audit quality is comprehensively determined by audit firm, engagement auditor, and institutions that regulate auditing. Audit firms hire, train, and evaluate audit personnel, and prescribe the testing procedures to be used on audit engagements and auditing takes place within the context of an audit firm. The engagement auditors collect and evaluate auditing evidence and make auditing judgment decisions based on the specific tests to be implemented and their interpretation of evidence from these tests. The audit outcome is an audit report that is issued in the name of audit firm, along with client's audited financial reports. In addition, the auditing procedures, auditors' incentives, and their behavior are influenced by the institutions that regulate auditing. One implication in Francis's (2011) framework is that audit clients also have influence on audit quality because financial statements are prepared by audit clients and the difficulty of collecting audit evidence varies among audit clients. Prior research has already investigated audit quality from several different perspectives.

\subsection{Audit Firm Characteristics And Audit Quality}

Studies of the U.S. audit market commonly argue that the audit quality is positively related to audit firm size. One of the most influential studies is DeAngelo (1981), who argues that auditors in large audit firms have more to lose if they fail to report breaches in clients' accounting reports, so they have greater motivation to provide higher quality audit services. Consistent with this argument, Becker et al. (1998) and Francis et al. (1999) document that Big N audit firms help to constrain firms' earnings management. Teoh and Wong (1993) find that the accounting information is more useful to investors if the companies who provide the information are audited by Big Eight audit firms. Francis and Krishnan (1999) find that Big Six audit firms are more conservative in issuing clean audit reports to their clients. Lennox (1999) documents that Big Four auditors issue more accurate audit reports than do the nonBig 4 audit firms. Pittman and Fortin (2004) find that the cost of capital is lower for Big Six clients relative to nonBig 6 clients.

Since the local practice audit offices are the primary decision-making unit for auditing firms, therefore, many scholars begin to investigate its effects on audit quality (Wallman, 1996; Francis et al., 1999). Francis and Yu (2009) argue that auditors in Big 4 audit offices have more collective experience in administering the audits of SEC registrants and, therefore, large audit offices have greater in-house expertise in detecting material problems in the financial statements of public companies. Francis and Yu (2009) find that larger Big 4 audit offices provide higher audit quality which indicated by larger Big 4 audit offices are more likely to issue going-concern audit reports and have better ability to constrain clients' aggressive earnings management behavior. Many other audit firm characteristics have been documented have the potential to influence audit quality, such as auditor tenure, auditor's 
industry expertise. Johnson et al. (2002), Ghosh and Moon (2005) find that auditor tenure is related to lower client aggressive earnings management behavior. Balsam et al. (2003) and Francis et al. (2005) document that industry expertise increases audit quality.

\subsection{Client Characteristics And Audit Quality}

Lawrence et al. (2011) find that the differences in audit quality are main attributed to client characteristics, which suggests that client characteristics are important factors that can influence audit quality. Many researchers argue that auditors have incentive to retain influential clients that may force them to compromise audit quality (Reynolds and Francis, 2000; Craswell et al., 2002). Knechel et al. (2009) develop a modified audit production framework based on Hackenbrack and Knechel $(1997)^{7}$, in which they take client-specific characteristics as exogenous factors that would affect both the use of different levels of audit staff and the extent of specific activities performed by audit staff. Knechel et al. (2009) find that audit quality is higher for clients that are larger, clients with extensive system automation, and clients with a December fiscal year-end, whereas, audit quality is lower for clients that receive tax services from the engagement auditor, clients that have subsidiaries, and engagements where the auditor relies on internal control. Francis and Yu (2009) argue that client operating segments and geographic segments will increase audit complexity and, therefore, can affect audit quality. Carcello and Neal (2000) and Abbott et al. (2004) find that the independence of client audit committee is one of the factors that may influence audit quality. Khan and Watts (2007) and Lu and Sapra (2009) find that clients with high business risk induce auditor conservatism, while clients with low business risk induce auditor aggressiveness. These empirical studies of client characteristics illustrate the importance of knowing more about the client who produces the financial report and its role in determining audit quality.

\subsection{Engagement Auditors And Audit Quality}

Engagement auditors is another important factor that can influence audit quality since they make judgment decisions based on audit tests, evaluation of evidence, and audit report formation. In one experimental study, Nelson and Tan (2005) call for attention to engagement auditor attributes in the design of judgment decision-making research. DeFond and Francis (2005) argues that the determinants of audit quality should be more significant at individual level, and they suggest that, if possible, the analysis of determinants of audit quality should be pushed to engagement auditor level. In the framework for understanding and researching audit quality, Francis (2011) argues that the audit quality will be higher when the auditors implementing audit tests are competent and independent.

Recently, more and more researchers pay attention to the effects of engagement auditor characteristics on audit quality. Carey and Simnett (2006) investigate the effects of a auditor's engagement tenure on audit quality and find that auditors with longer tenure have a lower propensity to issue going-concern report to their clients. Their results suggest that engagement auditors' objectivity might become impaired by long-term relationship with clients ${ }^{8}$. In contrast, Wang et al. (2012) find that engagement audit auditor experience increases both actual and perceived audit quality based on auditor tenure data in Chinese mainland. Specifically, they find that audit partner experience is negatively related to upwards earnings management, and positively associated with the likelihood of issuing going-concern opinions to financially distressed clients. They also find that earnings response coefficient and abnormal trading volume are higher for clients audited by engagement auditors with more experience. However, Chen et al. (2008) find no relationship between partner tenure and audit quality using partner data in Taiwan. Chin and Chi (2010) find that audits are of higher quality when the engagement auditor is a woman based on partner data in Taiwan. These archival researches of engagement auditor characteristics highlight the importance of knowing more about the person who audits and the effect it may have on audit quality.

As previously discussed, the archival literature on audit quality identifies audit firm, audit client, and engagement auditor as the important factors that have the power to influence audit quality. However, till now, there is no research quantifies the effects of each specific factor on the variance in audit quality. In this paper, we develop a framework based on Knechel et al. (2009) by considering audit firm-specific characteristics and engagement

\footnotetext{
${ }^{7}$ Hackenbrack and Knechel (1997) disaggregate labor hours into a matrix, classifying the hours by staff level and by type of audit activity.

${ }^{8}$ Bazerman et al. (1997) argue that it is difficult for engagement auditors to be skeptical and objective toward their longstanding clients.
} 
auditor-specific characteristics as the factors that can influence 'audit production' and thereby affect 'audit outcome' . In Figure 1, we also take audit as a production process and assume that engagement auditors expend their labor on the audit activities according to the particular audit process to generate the audit evidence, and conclude the 'audit outcome' based on the audit evidence. In the modified audit production framework, Knechel et al. (2009) treat client-specific characteristics as exogenous factors that affecting audit production process and 'audit outcome', but they did not consider the heterogeneity between audit firm and engagement auditor. In this paper, we consider the effects of audit firm-specific and engagement auditor-specific characteristics on audit quality besides the effects of client-specific characteristics, and decompose the variance in audit quality into the incremental explanatory power relate to audit firm, audit client, and engagement auditor, respectively. By doing this, we can identify the importance of audit firm-specific, audit client-specific, and engagement auditor-specific effects on audit quality.

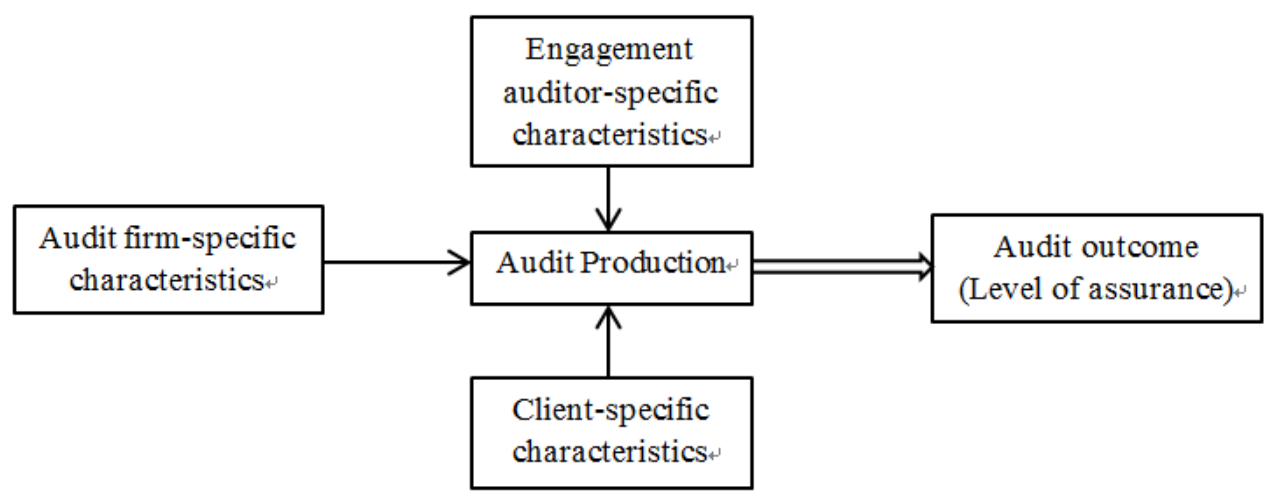

Figure 1. Framework For Determinants Of Audit Quality

\section{RESEARCH DESIGN}

\subsection{Research Model}

To identify the different effects of audit firm, audit client, and engagement auditor on audit quality, we employ a simultaneous ANOVA implemented using regression analysis. Simultaneous ANOVA allows for a full set of covariance effects but does not assume randomness in the model errors. The analysis relies on the following model of client-specific absolute discretionary accruals:

AB_DA ${ }_{k, \mathrm{i}, \mathrm{t}}=\eta_{\mathrm{t}}+\beta_{\mathrm{r}}+\delta_{\mathrm{k}}+\phi_{\mathrm{n}}+\varepsilon_{\mathrm{k}, \mathrm{i}, \mathrm{t}}$

In this equation, $A B_{-} D A_{k, i, t}$ is the absolute discretionary accruals in year $t$ of audit client $k$ in industry $i$. The absolute discretionary accruals calculated by modified Jones model developed by Dechow et al. $(1995)^{10}$. On the right-hand side, $\eta_{t}$ is the abnormal accruals associated with year $t ; \beta_{r}$ is the abnormal accruals associated with audit firm $r ; \delta_{k}$ is the abnormal accruals associated with audit client $k$; and $\phi_{n}$ is the abnormal accruals related to engagement auditor $n ; \varepsilon_{k, i, t}$ is the residual. This model is estimated using dummy variables to represent classes of effects.

\footnotetext{
${ }^{9}$ In the modified audit production framework, Knechel et al. (2009) take audit as a production unit in which the 'inputs' are engagement auditors' labor and the 'outputs' are audit activities, and the final 'outcome' is the level of assurance of the reliable of clients' financial reports. They assume that labor inputs are used in the audit process to perform audit activities that result in the generation of audit evidence and the greater the extent of evidence-gathering activities the greater likelihood that an auditor reaches the correct conclusion about whether the financial reports are misstated. Knechel et al. (2009) take client-specific characteristics as exogenous factors that affecting inputs, audit process, evidence-gathering activities, and evidence as a whole, and thus have an effect on audit outcome.

${ }^{10}$ In the untabulate tests, we use the performance adjusted discretionary accruals proposed by Kothari et al. (2005) as the proxy of audit quality, and we get the similar results. We also use the measure of discretionary accruals developed by Dechow and Dichev (2002), in which the measure of accrual quality as the residuals from firm-specific regressions of changes in working capital on past, present, and future operating cash flows, and the results are still robust.
} 
Instead of reporting the thousands of coefficients estimated for the full model, we present the results in the form of an ANOVA in which each class of effects is restricted. Year effects are defined to capture the general impact of macroeconomic fluctuations in business activities, and therefore restricted to be equal for all audit firms and audit clients. When audit firm or audit client effect is omitted from the full model, the engagement auditor effect picks up the variation in audit quality that would have been ascribed to audit firm or to audit client effect. The importance of audit firm effects and audit client effects is evaluated by assessing their explanatory power in models that exclude engagement auditor effects.

\subsection{Data And Sample Selection}

We obtain audit data including audit firms and engagement auditors from China Stock Market \& Accounting Research Database (CSMAR) ${ }^{11}$. Our sample period is from 1999 through 2012. We choose 1999 as the start because auditors separate both financially and operationally from government in that year ${ }^{12}$. Other financial data used in this research also from CSMAR.

Extant literature has documented that high quality audits constrain managers' ability to manipulate earnings in financial reporting (Becker et al., 1998; Francis et al., 1999; DeFond, 2002). Therefore, we surrogate audit quality with the absolute discretionary accruals in this paper. We estimate discretionary accruals using modified Jones model (Dechow et al., 1995) by year and industry conditioning on having at least 20 firms in each industry ${ }^{13}$. Following Plumlee and Yohn (2010) and Francis et al. (2013), we also use the "audit failure" which indicated by the happening of a downward restatement of financial report in previously audited client as the proxy of low audit quality $^{14}$.

We start with 24,013 firm-year observations available on CSMAR. We then eliminate 990 observations that belong to financial industry; we further delete 206 observations without industry information; finally we delete 3,330 observations without enough data to calculate discretionary accruals, arriving at 19,487 observations to test the associations between the effect of each factor and the variance in audit quality.

\subsection{Descriptive Statistics}

Table 1 reports the descriptive statistics of variables used in this research. The number of audit clients (listed companies) keeps growing from 1999 to 2012. In 1999, there are 839 audit clients in Chinese stock market, and this number grows more than twice by 2012, reaches to 2,402. In 1999, there were 106 audit firms that have the licenses to audit listed firms and this number decreased to 53 in 2012, which is because Chinese government promulgates several regulations to encourage audit firms to merge with each other in 2000 and $2009^{15}$. Although the audit firms keep decreasing, the number of engagement auditors keeps growing from 1999 to 2010. There are 2,589 engagement auditors in 2012, which is more than three times of the number in 1999. The average of absolute discretionary accruals is greater than 0.065 in most of the research periods, which is consistent with the findings in previous papers.

\footnotetext{
${ }^{11}$ CSMAR is analogous to COMPUSTAT. CSMAR provides information regarding financial statements of all the Chinese listed companies. Its sub-database for audit opinion of listed companies in China provides all the information regarding to audit, including audit firms and engagement auditors.

${ }^{12}$ Audit firms in China were affiliated to local government before 1999, and their operation was deeply intervened by local government.

${ }^{13}$ There are thirteen industries in Chinese stock market, because more than 50\% of China's listed firms are belong to Manufacture industry, so we divided Manufacture industry into 10 sub-industries according to the 2-digit industry code of CSRC.

${ }^{14}$ The Panel of Audit Effectiveness (2000, paragraphs 1.6 and 3.26) notes that a restatement is strongly suggestive that the audit of the originally issued financial statements was of unacceptably low quality.

${ }^{15}$ Ministry of Finance (MOF) issued three regulations in 2000 and each one in 2007 and 2009. These regulations first raise the thresholds for audit firms to get license to audit listed firms, and second these regulations encourage audit firms to merge with each other to form 10 Chinese big audit firms to compete with international big 4 audit firms.
} 
Table 1. Descriptive Statistics

\begin{tabular}{|c|c|c|c|c|c|}
\hline All years & No. ACs & No. AFs & No. EPs & Avg. DA & Median. DA \\
\hline 1999 & 839 & 106 & 670 & 0.064 & 0.044 \\
\hline 2000 & 970 & 70 & 752 & 0.065 & 0.046 \\
\hline 2001 & 1,116 & 71 & 864 & 0.069 & 0.046 \\
\hline 2002 & 1,189 & 71 & 957 & 0.069 & 0.045 \\
\hline 2003 & 1,245 & 72 & 1,040 & 0.071 & 0.044 \\
\hline 2004 & 1,341 & 72 & 1,230 & 0.071 & 0.047 \\
\hline 2005 & 1,428 & 70 & 1,317 & 0.063 & 0.042 \\
\hline 2006 & 1,427 & 68 & 1,449 & 0.068 & 0.045 \\
\hline 2007 & 1,505 & 64 & 1,594 & 0.157 & 0.080 \\
\hline 2008 & 1,616 & 50 & 1,690 & 0.115 & 0.055 \\
\hline 2009 & 1,650 & 60 & 1,798 & 0.102 & 0.051 \\
\hline 2010 & 1,799 & 54 & 2,146 & 0.113 & 0.068 \\
\hline 2011 & 2,149 & 53 & 2,344 & 0.145 & 0.069 \\
\hline 2012 & 2,402 & 53 & 2,589 & 0.073 & 0.039 \\
\hline
\end{tabular}

No. ACs is number of audit clients; No.AFs is number of audit firms; No.EPs is number of engagement partners; Avg.DA is the average of absolute discretionary accruals; Median.DA is the median of absolute discretionary accruals.

\section{EMPIRICAL RESULTS}

One outstanding question raised by Francis (2011) is how to understand the role of engagement auditor in determining audit quality. Another outstanding question raised by Lawrence et al. (2012) is how to separate the effects of audit client characteristics on audit quality. In this section, we show the results of a simultaneous ANOVA approach for Equation (1) in comparison with the results for a variety of related models where restrictions have imposed on. We also show the incremental explanatory power associated with year, audit firm, audit client, and engagement auditor effects, respectively.

The results of the analysis-of-variance on Equation (1) are shown in Figure 2. The model at the bottom of the figure incorporates the year effects, audit firm effects, audit client effects, and engagement auditor effects, which corresponds to the fully specified model in Equation (1). All other entries in Figure 2 correspond to model in which at least one class of effects is restricted to zero. Figure 2 also shows the ordinary and adjusted $\mathrm{R}^{2}$ for each model. Each line is accompanied by the probability at which an F-test rejects the corresponding restriction using Vuong's (1989) Likelihood Ratio Tests (LRT) for model selection.

Consider first the fully specified model at the bottom of Figure 2, which includes all the effects of year, audit firm, audit clients, and engagement auditor. Each of the lines immediately above this model points to a model in which one type of effect is omitted ${ }^{16}$. From the left, the first two of these lines are associated with restrictions on engagement auditor and audit client effects, respectively. In each case, the level of the F-test rejects the restriction with $1 \%$ confidence, which indicates that the engagement auditor effects and audit client effects significantly account for audit quality. The third line points to a model in which audit firm effects are restricted. The F-test does not reject the exclusion because audit firm effects are linear by design with engagement auditor effects. When comparing models, we invoke the inherent "nested" nature of an ANOVA. The description of our models as "simultaneous" ANOVA derives from the fact that each model present in the figure is estimated while accounting for covariance between the estimated effects.

The next-highest layer of Figure 2 contains three models in which three of the four effects are reported. The first model of the second-highest layer includes year, audit firm, and engagement auditor effects. The model generates an $\mathrm{R}^{2}$ of 0.1969 , which is significantly different from the $\mathrm{R}^{2}(0.3877)$ of the full-specific model at the bottom of Figure 2, indicating that audit client can add significant explanation power to audit quality. The second model of the second-highest layer includes year, audit firm, and audit client effects. The model generates an $\mathrm{R}^{2}$ of 0.2483 , which is significantly different from the $\mathrm{R}^{2}(0.3877)$ of the full-specific model at the bottom of Figure 2 , indicating that audit partner can add significant explanation power to audit quality. The third model of the secondhighest layer includes year, audit client, and audit partner effects. The model generates an $\mathrm{R}^{2}$ of 0.3825 , which is not

\footnotetext{
${ }^{16}$ For simplicity, Figure 1 does not show the results for the models that exclude the year effects. Year effects are significant.
} 
significantly different from the $\mathrm{R}^{2}(0.3877)$ of the full-specific model at the bottom of Figure 2, indicating that audit firm cannot add significant explanation power to audit quality because of linearity by design with audit client effects. These results provide evidence that audit client and audit partner effects significantly contribute to explanatory power to audit quality.

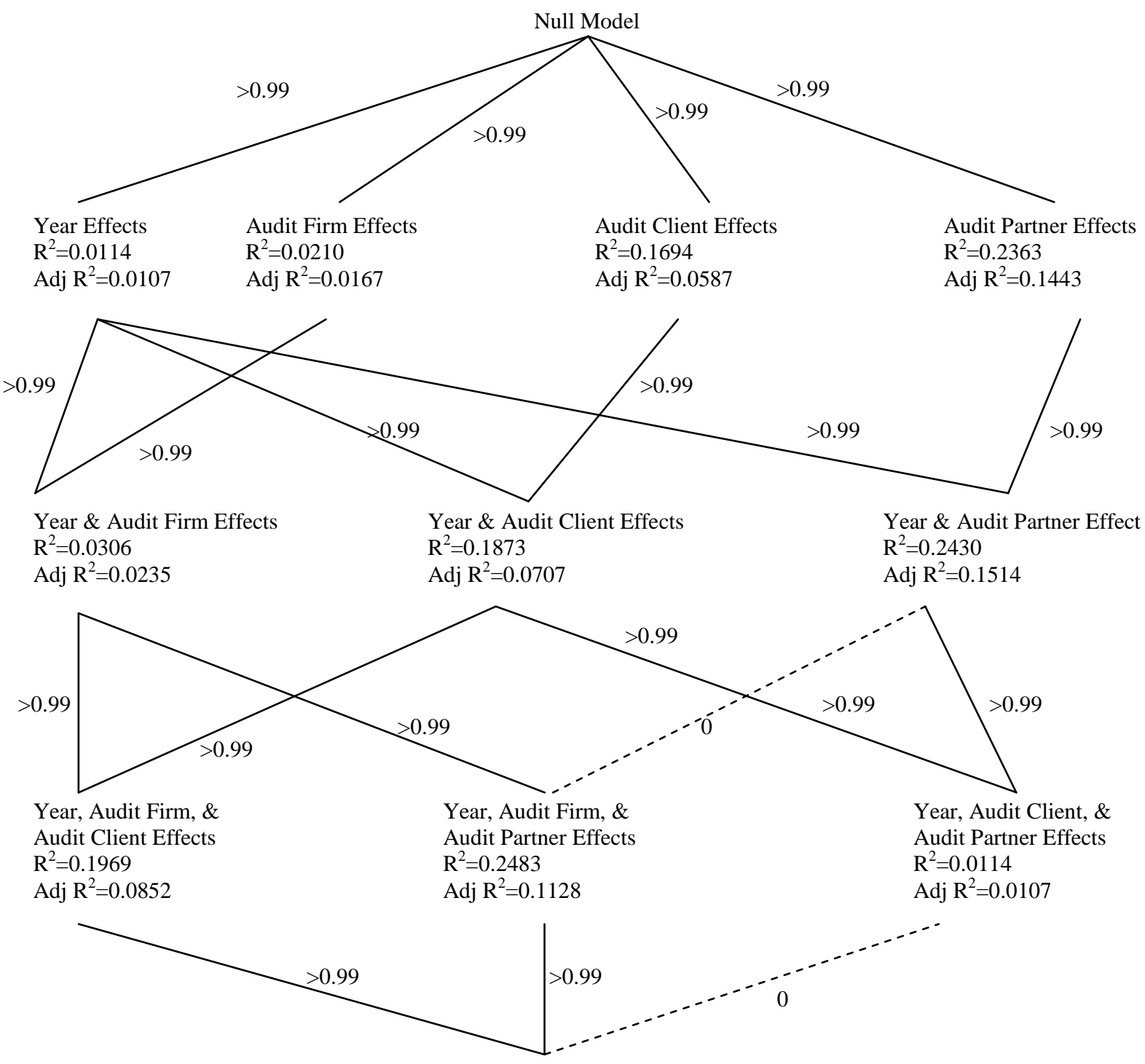

Year, Audit Firm, Audit Client,

\& Audit Partner Effects

$\mathrm{R}^{2}=0.3877$

Adj $R^{2}=0.1821$

Figure 2. Analysis Of Variance On Equation (1)

Note: This figure reports the estimated rate of correlation, the $\mathrm{R}^{2}$, and the adjusted $\mathrm{R}^{2}$ in models that include various set of effects. Each line is accompanied by a figure that represents the probability with which the model rejects the restriction indicated by comparing the two models. For example, the model at the bottom of the figure includes year, audit firm, audit client, and audit partner effects, and generates an $\mathrm{R}^{2}$ of 0.3877 . The model immediately above it excludes the audit client effects, and generates an $\mathrm{R}^{2}$ of 0.2483 . The difference in the explanatory power of the two models is significant at the $99 \%$ level, and indicate by the " $>0.99$ " that accompanies the restriction. Thus, the analysis shows that audit client effects add significant explanatory power to audit quality even in a model that already includes year, audit firm, and audit partner. 
The third-highest group of lines corresponds to restrictions on models in which two of four effects are presented. Audit client and audit partner effects have important explanatory power in the fixed-effects model. Audit firm has incremental explanatory power in the model of year, audit firm, and audit client effects in compare with model of year and audit client effects. However, the incremental explanatory power of audit firm vanished in the model of year, audit firm, and audit partner because of the linearity by design. The adjusted $\mathrm{R}^{2}$ drops by a relatively small amount when audit firm is removed from the model with year, audit firm, and audit client effects. The remaining models also reject the exclusion of all effects.

The final group of restrictions at the top of the figure provides information about the explanatory power of each type of effect on its own. In compare with the null model, the explanatory power of year effects, audit firm effects, audit client effects, and audit partner effects is $0.0114,0.0210,0.1694$, and 0.2363 , respectively. When only one of the classes of effects is present, the F-statistic never rejects the restriction to the null model. In sum, Figure 2 confirms that all four types of effects: year, audit firm, audit client, and audit partner, are justified for inclusion in the full model.

Table 2 displays the results from Figure 2 on the incremental explanatory power for each type of effect. To construct Table 2 , we calculated the incremental explanatory power to the ordinary and adjusted $\mathrm{R}^{2}$ with effects introduced in the following order: year, audit firm, audit client, and audit partner ${ }^{17}$. Year effects add just over $1 \%$ to both ordinary and adjusted $\mathrm{R}^{2}$. Audit firm effects add less than $2 \%$ to both ordinary and adjusted $\mathrm{R}^{2}$. Audit client effects add 6\%-17\% and audit partner effects add 9\%-20\%. Therefore, audit client effects and audit partner effects are two of more important effects than the other two types of effects, and the audit partner effects is of the most important among all type of effects. Thus, the findings in this paper generally provide evidence that audit client and audit partner are two of the most important factors in determining audit quality.

Table 2. Incremental Explanatory Power By Each Type Of Effect

\begin{tabular}{lcc}
\hline & Ordinary $\mathbf{R}^{\mathbf{2}}$ & Adjusted R $^{\mathbf{2}}$ \\
\hline Year $^{\mathrm{a}}$ & $1.14 \%$ & $1.07 \%$ \\
Audit Firm $^{\mathrm{b}}$ & $1.92 \%$ & $1.28 \%$ \\
Audit Client $^{\mathrm{c}}$ & $16.63 \%$ & $6.17 \%$ \\
Audit Partner & $19.08 \%$ & $9.69 \%$ \\
Fall Model & $38.77 \%$ & $18.21 \%$ \\
\hline
\end{tabular}

Notes:

${ }^{a}$ Incremental explanatory power in model of year effects over null model.

${ }^{\mathrm{b}}$ Incremental explanatory power in model of year and audit firm effects over model of year effects.

${ }^{\mathrm{c}}$ Incremental explanatory power in model of year, audit firm, and audit client effects over model of year and audit firm effects.

${ }^{\mathrm{d}}$ Incremental explanatory power in full model over model of year, audit firm, and audit client effects.

In the untabulated results, the rate of serial correlation in residuals $(\rho)$ also calculated for each of the model. For the full model at the bottom of Figure 2, the rate of serial correlation in residuals is $23.8 \%$. In restricted models, the rate of serial correlation in residuals is higher because the residuals include the omitted effects. In the full model, the rate of serial correlation represents the tendencies of shocks in a specific year to affect audit quality in the subsequent year. Because the effects of audit firm and engagement auditor are defined to apply across the entire 14year period, the serial correlation in the residuals reflects any shock with intertemporal influence greater than one year but less than the full 14-year period under study.

Table 3 presents the results from models corrected for serial correlation. The first column reports the results from the uncorrected model for reference. The second column displays results when each of the constituent models (i.e., the model of year effects, the model of year and audit firm effects, the model of year, audit firm, and audit client effects, and the model of year, audit firm, audit client, and engagement auditor effects) is corrected for its own estimated serial correlation. The results are substantially close to those in the uncorrected model. The approach used in this paper is the standard method for dealing with serial correlation, which generates $\mathrm{R}^{2}$ that are based on different sums of squares because observations are corrected for different rates of serial correlation in each model. The results

\footnotetext{
${ }^{17}$ If engagement auditor effects were introduced before audit firm effects, then audit firm effects would have no explanatory power because audit quality differences in audit firm would be previously captured in the engagement auditor effects. We believe that this order of introduction would be minimally informative.
} 
displayed in the third column of Table 3 report the incremental explanatory power $\left(\mathrm{R}^{2}\right)$ by each type of effects after dealing with serial correlation ${ }^{18}$. The $\mathrm{R}^{2}$ in the models are directly comparable with each other because all the models have the total sum of squares. The results for models after dealing with serial correlation are similar to those before dealing with serial correlation, which indicate that the results find in this paper are robust. That is, beside the audit firm, audit client and engagement auditor are two of the most important factors in the determination of audit quality.

Table 3. Incremental Explanatory Power By Each Type Of Effect In Models Dealing With Serial Correlation

\begin{tabular}{lccc}
\hline & Uncorrected Model & Standard Correction & Correction On Full Model \\
\hline Year $^{\mathrm{a}}$ & $1.14 \%$ & $1.03 \%$ & $1.04 \%$ \\
Audit firm $^{\mathrm{b}}$ & $1.92 \%$ & $1.88 \%$ & $1.90 \%$ \\
Audit client & $\mathrm{c}$ & $16.21 \%$ & 16.25 \\
Audit partner & $16.63 \%$ & $18.73 \%$ & $18.20 \%$ \\
Full model & $19.08 \%$ & $38.42 \%$ & $37.93 \%$ \\
\hline
\end{tabular}

Notes:

${ }^{\mathrm{a}}$ Incremental explanatory power in model of year effects over null model.

${ }^{\mathrm{b}}$ Incremental explanatory power in model of year and audit firm effects over model of year effects.

${ }^{c}$ Incremental explanatory power in model of year, audit firm, and audit client effects over model of year and audit firm effects.

${ }^{\mathrm{d}}$ Incremental explanatory power in full model over model of year, audit firm, and audit client effects.

\section{SENSITIVIEY TESTS}

In the prior section, using absolute discretionary accruals as the proxy of low audit quality, this paper has documented that audit client and engagement auditor are two of most important factors to the variance of audit quality, which can add about $16 \%$ and $19 \%$ of incremental explanatory power. However, the absolute discretionary accruals only can reflect audit quality on a certain aspect, which is the auditor's ability to constraint managements' discretion in reporting earnings. For the robustness, it requires us to find other ways to measure audit quality. Palmorse and Scholz (2004) and Kinney et al. (2004) argue that a material restatement of audited financial statements is a strong signal that the audit was of low quality. Panel on Audit Effectiveness (PAE) (2000) states "Restatements also raise the question, 'Where were the auditors?' suggesting that there may be something wrong with the very concept of audits performed private-sector auditors who are largely self-regulated." (PAE Par. 1.6). PAE also states "Restatements of previously audited financial statements raise questions about whether the system that provides assurances about both the quality of audits and the reliability of financial reports is operating effectively" (PAE Par.3.26). After investigating 3,744 financial restatements, Plumlee and Yohn (2010) identify four main reasons for financial restatements: internal company error, intentional manipulation, transaction complexity, and characteristics of accounting standards. Francis and Michas (2013) believe that the external auditor bears some responsibility for allowing a company to issue misstated financial statements due to any of these four reasons of restatements, and Francis and Michas (2013) use financial restatement as proxy of low audit quality. Therefore, following Palmorse and Scholz (2004), Kinney et al. (2004), and Francis and Michas (2013), we also use financial restatement as the proxy of low audit quality in this section, analyzing the variance of audit quality.

Financial restatement (FR) is a dummy variable, which equals one when a client restates net income downward, otherwise it equals zero. Here, we use FR to substitute the dependent variable in Equation (1) and the independent variables are the same as in Equation (1). Table 4 reports the results of incremental explanatory power for each specific effects (Year, Audit firm, Audit client, and Engagement auditor). The year effects, audit firm effects, audit client effects, and engagement auditor effects can add about 2\%, 4\%, 6\%, and $19 \%$ of incremental explanatory, respectively. Although the difference of incremental explanatory power between audit firm effects and audit client effects is much smaller than the results in Table 2, audit client effects is still the second most important factor in determining audit quality which accounts for about $6 \%$ of incremental explanatory power in the variance of audit quality. Similar to the results presented in Table 2, the engagement auditor effects is still the most important factor in determination of audit quality which accounts for about $19 \%$ of incremental explanatory power in the variance of audit quality. Table 5 presents the results after dealing with serial correlation, the results have no

\footnotetext{
${ }^{18}$ The results are based on the estimates generated by the standard serial correlation (from Column 2) and the total sums of squares on the uncorrected data
} 
significant difference with the results before dealing with serial correlation. The results displayed in Tables 4 and 5 provide additional evidence that audit clients and audit auditors are two of the most important factors in determining audit quality.

Table 4. Incremental Explanatory Power By Each Type Of Effect (Dependent Variable: Financial Restatement)

\begin{tabular}{lc}
\hline & Pseudo R $^{2}$ \\
\hline Year $^{\mathrm{a}}$ & $2.24 \%$ \\
Audit Firm $^{\mathrm{b}}$ & $4.32 \%$ \\
Audit Client $^{\mathrm{c}}$ & $6.20 \%$ \\
Audit Partner $^{\mathrm{d}}$ & $19.08 \%$ \\
Fall Model & $31.84 \%$ \\
\hline
\end{tabular}

Notes:

${ }^{a}$ Incremental explanatory power in model of year effects over null model.

${ }^{b}$ Incremental explanatory power in model of year and audit firm effects over model of year effects.

${ }^{\mathrm{c}}$ Incremental explanatory power in model of year, audit firm, and audit client effects over model of year and audit firm effects.

${ }^{\mathrm{d}}$ Incremental explanatory power in full model over model of year, audit firm, and audit client effects.

Table 5. Incremental Explanatory Power By Each Type Of Effect In Models Dealing With Serial Correlation (Dependent Variable: Financial Restatement)

\begin{tabular}{lccc}
\hline & Uncorrected Model & Standard Correction & Correction On Full Model \\
\hline Year $^{\mathrm{a}}$ & $2.24 \%$ & $2.20 \%$ & $2.23 \%$ \\
Audit firm $^{\mathrm{b}}$ & $4.32 \%$ & $4.41 \%$ & $4.45 \%$ \\
Audit client $^{\mathrm{c}}$ & $6.20 \%$ & $6.21 \%$ & 6.16 \\
Audit partner $^{\mathrm{d}}$ & $19.08 \%$ & $18.94 \%$ & $18.59 \%$ \\
Full model & $31.84 \%$ & $31.57 \%$ & $31.24 \%$ \\
\hline
\end{tabular}

Notes:

${ }^{\text {a }}$ Incremental explanatory power in model of year effects over null model.

${ }^{\mathrm{b}}$ Incremental explanatory power in model of year and audit firm effects over model of year effects.

${ }^{\mathrm{c}}$ Incremental explanatory power in model of year, audit firm, and audit client effects over model of year and audit firm effects.

${ }^{\mathrm{d}}$ Incremental explanatory power in full model over model of year, audit firm, and audit client effects.

For the robustness, we also surrogate audit quality with: (1) absolute value of performance adjusted discretionary accruals proposed by Kothari et al (2005) and the abnormal working capital accruals proposed by Dechow and Dichev (2002) ${ }^{19}$. The untablated results are similar to the results in Table 2. The CSRC enforcement action is the direct measure of low audit quality, but there are only 89 engagement auditors punished by CSRC during our sample period. Therefore, we use financial restatements and/or engagement partners penalties as the proxy of low audit quality, and we get the similar results when only use financial restatements as the proxy of low audit quality.

\section{ADDITIONAL TESTS}

The analyses displayed in sections 4 and 5 resolve an important question about the variance in audit quality using simultaneous ANOVA method. The results indicate that engagement auditor is the most important factor in determining audit quality, which can add about $19 \%$ of incremental explanatory power. To some extent, this finding provides some quantitative evidence to several recent studies, in which they focus on engagement auditors' role in determining audit quality (Chi and Huang, 2005; Carey and Simnett 2006; Chi et al. 2009; Chen et al. 2010; Wang et al. 2012). Using engagement auditor data from Taiwan, Chi and Huang (2005) find evidence consistent with lower audit quality in the early years of auditor tenure and later years of tenure, Chi et al. (2009) find that investors perceive mandatory audit-partner rotation as enhancing audit quality. Based on engagement auditor data from Australia, Carey and Simnett (2006) find that longer engagement auditor tenure associated with lower propensity to issue going-concern audit opinion. Using engagement auditor data from China mainland, Wang et al. (2012) find that engagement auditors' total audit experience is positively associated with audit quality.

\footnotetext{
${ }^{19}$ The abnormal working capital accruals captures the degree to which working capital accruals fail to map into past, current, and future cash flows developed by Dechow and Dichev (2002).
} 
Given the important of engagement auditors' audit experience in determining audit quality, engagement auditor with different kind of audit experience may have different incremental explanatory power. To shed further light on the determinants of variance in audit quality, following Wang et al. (2012), we decompose audit experience into auditors' general audit experience and client-specific audit experience. The general audit experience refers to the total number of years since from an auditor first sign his/her name on the audit report. We expect that engagement auditor with longer audit experience have higher audit quality, and therefore may have more incremental explanatory power to the variance in audit quality. The client-specific audit experience refers to the total number of years that an auditor signs his/her name on a special client's financial report. Chi and Huang (2005) and Carey and Simnett (2006) suggest deterioration in audit quality in the early years of tenure due to the loss of clientspecific knowledge and expertise, and they also suggest that the long tenure may impair engagement auditor's independence which may cause low audit quality. Chi and Huang (2005) and Carey and Simnett (2006) conclude that auditors in medium-term audit tenure have higher audit quality. According to Chi and Huang (2005) and Carey and Simnett (2006) and the relative policies in China, we expect that the audit quality should be at its maximum when the audit tenure between 3 to 5 years ${ }^{20}$.

In this section, we use two sub-samples to investigate whether engagement auditor tenure can mediate the relationship between audit quality and engagement auditor. One sub-sample includes engagement partners with general audit experience greater than the median, and the other sub-sample includes engagement auditors with medium client-specific audit experience (the audit tenure is between 3 to five years). Using the simultaneous ANOVA method, Table 6 displays the incremental explanatory power of each effects according to Equation (1) based on sub-samples. Panel A and B report the incremental explanatory power of each effects using general audit experience sub-sample and client-specific experience sub-sample, respectively. Surprisingly, the longer general audit experience and the medium client-specific audit experience add no more incremental explanatory power to the variance in audit quality. The findings here consistent with the conclusions in the current literature, most of the studies find mixed results or no results about the impact of engagement auditor tenure on audit quality. Table 7 reports the results after dealing with serial correlation using general audit experience sub-sample and client-specific experience sub-sample. The results in Panel A and B of Table 7 have no significant difference from the results in Panel A and B of Table 6.

Table 6. Incremental Explanatory Power By Each Type Of Effects Based On Sub-Samples

\begin{tabular}{|c|c|c|}
\hline & Ordinary $\mathbf{R}^{2}$ & Adjusted R $\mathbf{R}^{2}$ \\
\hline \multicolumn{3}{|c|}{ Panel A Incremental explanatory power by each type of effects based on general experience sub-sample } \\
\hline Year $^{\mathrm{a}}$ & $1.09 \%$ & $1.04 \%$ \\
\hline Audit Firm ${ }^{\mathrm{b}}$ & $1.87 \%$ & $1.21 \%$ \\
\hline Audit Client ${ }^{\mathrm{c}}$ & $16.19 \%$ & $6.06 \%$ \\
\hline Audit Partner ${ }^{\mathrm{d}}$ & $18.75 \%$ & $9.58 \%$ \\
\hline Fall Model & $37.46 \%$ & $18.04 \%$ \\
\hline \multicolumn{3}{|c|}{ Panel B Incremental explanatory power by each type of effects based on client-specific experience sub-sample } \\
\hline Year $^{\mathrm{a}}$ & $1.10 \%$ & $1.03 \%$ \\
\hline Audit Firm ${ }^{\mathrm{b}}$ & $1.92 \%$ & $1.25 \%$ \\
\hline Audit Client ${ }^{\mathrm{c}}$ & $16.37 \%$ & $6.11 \%$ \\
\hline Audit Partner ${ }^{\mathrm{d}}$ & $18.83 \%$ & $9.64 \%$ \\
\hline Fall Model & $37.69 \%$ & $18.10 \%$ \\
\hline
\end{tabular}

Notes:

${ }^{a}$ Incremental explanatory power in model of year effects over null model.

${ }^{\mathrm{b}}$ Incremental explanatory power in model of year and audit firm effects over model of year effects.

${ }^{\mathrm{c}}$ Incremental explanatory power in model of year, audit firm, and audit client effects over model of year and audit firm effects.

${ }^{\mathrm{d}}$ Incremental explanatory power in full model over model of year, audit firm, and audit client effects.

\footnotetext{
${ }^{20}$ In U.S., the regulation requires that the lead engagement auditor and audit review partner be rotated every five years on public company engagements after the Sarbanes-Oxley Act of 2002. Australia and Taiwan, the regulations also require that the engagement auditors should be mandatory rotation every five years. In China, the relative regulations require that the state-owned enterprise should rotate its engagement auditor every five years.
} 
Table 7. Incremental Explanatory Power By Each Type

Of Effects Based On Sub-Samples In Models After Dealing With Serial Correlation

Uncorrected Model Standard Correction

Correction On Full Model

\begin{tabular}{|c|c|c|c|}
\hline \multicolumn{4}{|c|}{$\begin{array}{l}\text { Panel A Incremental explanatory power by each type of effects based on general experience sub-sample in models after } \\
\text { dealing with serial correlation }\end{array}$} \\
\hline Year $^{\mathrm{a}}$ & $1.09 \%$ & $0.96 \%$ & $1.01 \%$ \\
\hline Audit Firm ${ }^{\mathrm{b}}$ & $1.87 \%$ & $1.85 \%$ & $1.87 \%$ \\
\hline Audit Client $^{\mathrm{c}}$ & $16.19 \%$ & $15.78 \%$ & $16.09 \%$ \\
\hline Audit Partner ${ }^{\mathrm{d}}$ & $18.75 \%$ & $18.22 \%$ & $18.76 \%$ \\
\hline Fall Model & $37.46 \%$ & $37.01 \%$ & $37.33 \%$ \\
\hline \multicolumn{4}{|c|}{$\begin{array}{l}\text { Panel B Incremental explanatory power by each type of effects based on client-specific experience sub-sample in models } \\
\text { after dealing with serial correlation }\end{array}$} \\
\hline Year $^{\mathrm{a}}$ & $1.10 \%$ & $0.94 \%$ & $0.99 \%$ \\
\hline Audit Firm ${ }^{\mathrm{b}}$ & $1.92 \%$ & $1.88 \%$ & $1.90 \%$ \\
\hline Audit Client $^{\mathrm{c}}$ & $16.37 \%$ & $16.02 \%$ & $16.11 \%$ \\
\hline Audit Partner ${ }^{\mathrm{d}}$ & $18.83 \%$ & $18.27 \%$ & $18.54 \%$ \\
\hline Fall Model & $37.69 \%$ & $37.36 \%$ & $37.55 \%$ \\
\hline
\end{tabular}

Notes:

${ }^{\text {a }}$ Incremental explanatory power in model of year effects over null model.

${ }^{\mathrm{b}}$ Incremental explanatory power in model of year and audit firm effects over model of year effects.

${ }^{\mathrm{c}}$ Incremental explanatory power in model of year, audit firm, and audit client effects over model of year and audit firm effects.

${ }^{\mathrm{d}}$ Incremental explanatory power in full model over model of year, audit firm, and audit client effects.

We also use financial restatements and CSRC enforcement actions to surrogate low audit quality, the results have no significant difference from the results displayed in Table 4 and 5.

\section{CONCLUSIONS}

Motivated by the intensifying worldwide interest in, but insufficient empirical evidence of, whether the audit client and engagement audit auditor matter to variance of audit quality, we investigate this issue by exploring the Chinese audit and stock market where engagement audit auditors are mandated to sign audit reports.

Using discretionary accruals and financial restatement as proxies of audit quality and based on simultaneous ANOVA method, we find that engagement auditor is the most important factor in determining audit quality, which can add about $19 \%$ of incremental explanatory power to the variance in audit quality. In addition to engagement auditor, we find that audit client effects can add about $16 \%$ of incremental explanatory power to the variance in audit quality, which support the recent argument by many scholars that it is audit client characteristics that cause the significant difference in audit quality instead of the audit firm itself (Chen et al. 2010; Lawrence et al. 2011). Not surprisingly, the audit firm effects only add about $2 \%$ of incremental explanatory power to the variance in audit quality, which provide further support to the argument. The results are robust when we use other methods to measure audit quality. In the additional tests, we find that engagement auditors with more general and/or firmspecific audit experience cannot significantly increase engagement auditor's importance in determining audit quality.

This paper contributes to literature from two aspects. First, this paper explores the role of audit client in determining audit quality. Literature on audit quality only investigates the variance of audit quality from the perspective of audit firm characteristics. Recently, Lawrence et al. (2011) argue that the variety of audit quality between Big 4 and non-Big 4 audit firms is due to audit client characteristics, and they encourage researchers to explore alternative methodologies to separate audit client characteristics from audit-quality. The findings of this paper that audit firm and audit client add about $2 \%$ and $16 \%$ of incremental explanatory power to the variance of audit quality, respectively, providing some empirical evidence to the argument of Lawrence et al. (2011). Second, this paper investigates the role of engagement audit auditor in determining audit quality. Public Oversight Board state "The most important determinants of audit effectiveness are the personal attributes and skills of the individual auditor" (2000). Francis (2011) encourages that future research on audit quality should pay attention to engagement auditors' role in determining audit quality. However, except for experimental researches provide some evidence that audit quality varies with individual auditor characteristics (Nelson and Tan 2005; Nelson 2009), there is no 
empirical study investigating engagement auditors' role based on large sample. This study fills in this gap, and finds that engagement auditor is the most important factor in determining audit quality.

The evidence of this paper has policy implications to regulators. The findings of this paper that individual engagement auditors have significant influence over audit quality provide support to the mandatory auditor signature. This study also has research implications. The findings of this paper indicate that it is important to study audit quality from perspectives of audit client and individual engagement auditor. Future researches should study the relations between audit quality and audit client and individual audit auditor from other perspectives.

\section{ACKNOWLEDGEMENTS}

This paper is financial supported by China Postdoctoral Science Foundation (2014M550505) and National Natural Science Foundation of China (71102095, 71372163, 71302195).

\section{AUTHOR INFORMATION}

Baolei Qi is an assistant professor in School of Management, Xi'an Jiaotong University, P.R. China.

Bin Li is a post doctor in School of Management, Xi'an Jiaotong University, P.R. China. E-mail: libin@mail.xjtu.edu.cn (corresponding author)

Gaoliang Tian is a professor in School of Management, Xi'an Jiaotong University, P.R. China.

\section{REFERENCE}

1. Abbott, L., S. Parker, \& G. Peters. (2004). Audit committee characteristics and restatements. Auditing: A Journal of Practice \& Theory 23 (1): 69-87.

2. Antle, R., \& B. Nalebuff. (1991). Conservatism and auditor-client negotiations. Journal of Accounting Research 29 (supplement): 31-54.

3. Balsam, S., J. Krishnan, \& J. Yang. (2003). Auditor industry specialization and earnings quality. Auditing: A Journal of Practice \& Theory 22 (2): 71-97.

4. Bazerman, M., K. Morgan, \& G. Loewenstein. (1997). The impossibility of auditor independence. Sloan Management Review 38 (4): 89-94.

5. Becker, C., M. DeFond, J. Jiambalvo, \& K. R. Subramanyam. (1998). The effect of audit quality on earnings management. Contemporary Accounting Research (1): 1-24.

6. Behn, B., J. Choi, \& T. Kang. (2008). Audit quality and properties of analysts' earnings forecasts. The Accounting Review (2): 327-349.

7. Carey, P., \& R. Simnett. (2006). Audit partner tenure and audit quality. The Accounting Review 81 (3):653676.

8. Carcello, J., \& T. Neal. (2000). Audit committee composition and auditor reporting. The Accounting Review 75 (4): 453-467.

9. Chen, C., C. Lin, \& Y. Lin. (2008). Audit partner tenure, audit firm tenure, and discretionary accruals: Does long auditor tenure impair earnings quality? Contemporary Accounting Research 25 (2): 415-444.

10. Chen, S., Y. J .Sun, \& D. Wu. (2010). Client importance, institutional improvements, and audit quality in China: An office and individual auditor level analysis. The Accounting Review, 85 (1): 127-158.

11. Chi, W, \& H. Huang. (2005). Discretionary accruals, audit-firm tenure and audit partner tenure: Empirical evidence from Taiwan. Journal of Contemporary Accounting \& Economics 1 (1): 65-92.

12. Chi, W., H. Huang, Y. Liao, \& H. Xie. (2009). Mandatory audit partner rotation, audit quality, and market perception: Evidence from Taiwan. Contemporary Accounting Research 26 (2): 359-391.

13. Chin, C., \& H. Chi. (2010). Gender differences in audit quality. Working Paper, National Chengchi University and National Chung Hsing University.

14. Choi, J., C. Kim, \& Y. Zang. (2010). Audit office size, audit quality, and audit pricing. Auditing: A Journal of Practice \& Theory 29 (1): 73-97. 
15. Craswell, A., D. Stokes, \& J. Laughton. (2002). Auditor independence and fee dependence. Journal of Accounting and Economics 32 (2): 253-275.

16. DeAngelo, L. (1981). Auditor size and audit quality. Journal of Accounting and Economics 3 (3): 183-199.

17. Dechow, P. M, \& L. D. Dichev. (2002). The quality of accruals and earnings: The role of accruals estimation errors. The Accounting Review 77 (Supplement): 35-59.

18. Dechow, P. M., R. G. Solan, \& A. P. Sweeney. (1995). Detecting earnings management. The Accounting Review 70 (2): 193-225.

19. DeFond, M. L. (2002). Discussion of the balance sheet as an earnings management constraint. The Accounting Review 77 (Supplement): 29-33.

20. DeFond, M.L., \& J. R. Francis. (2005). Audit research after Sarbanes-Oxley. Auditing: A Journal of Practice \& Theory 24 (Supplement): 5-30.

21. Ferguson, A., J. Francis, \& D. Stokes. (2003). The effects of firm-wide and office-level industry expertise on audit pricing. The Accounting Review 78 (2): 429-448.

22. Francis, J. (2011). A framework for understanding and researching audit quality. Auditing: A Journal of Practice \& Theory 30 (2): 125-152.

23. Francis, J., E.L. Maydew, \& H.C. Sparks. (1999). The role of Big 6 auditors in the credible reporting of accruals. Auditing: A Journal of Practice \& Theory 18 (2): 17-34.

24. Francis, J., K. Reichelt, \& D. Wang. (2005). The pricing of national and city-specific reputations for industry expertise in the U.S. audit market. The Accounting Review 80 (1):113-136.

25. Francis, J., \& J. Krishnan. (1999). Accounting accruals and auditor reporting conservatism. Contemporary Accounting Research 16 (1): 135-165.

26. Francis, J., \& M. Yu. (2009). The effect of Big 4 office size on audit quality. The Accounting Review 84 (5): 1521-1552.

27. Francis, J., \& P. N. Michas. (2013). The contagion effect of low-quality audits. The Accounting Review 88 (2): 521-552.

28. Ghosh, A, \& D. Moon. (2005). Auditor tenure and perceptions of audit quality. The Accounting Review 80 (2): 585-612.

29. Gibbins, M., S. McCracken, \& S. Salterio. (2010). The auditor's strategy selection for negotiation with management: Flexibility of initial accounting position and nature of the relationship. Accounting, Organizations and Society 35 (6): 579-595.

30. Hackenbrack, K., \& W. R. Knechel. (1997). Resource allocation decisions in audit engagements. Contemporary Accounting Research 14 (3):481-499.

31. Hurrt, R. Kathy. (2010). Development of scale to measure professional skepticism. Auditing: A Journal of Practice \& Theory 29 (1): 149-171.

32. Kahn, M., \& R. Watts. (2009). Estimation and empirical properties of a firm-year measure of accounting conservatism. Journal of Accounting and Economics 48 (2-3): 132-150.

33. Khurana, I., \& K. K. Raman. (2004). Are Big 4 audits in ASEAN countries of higher quality than non-Big 4 audits? Asia Pacific Journal of Accounting and Economics 11 (2): 139-165.

34. Kinney, W. R., Z. V. Palmrose, \& S. Scholz. (2004). Auditor independence, non-audit services, and restatements: Was the U. S. government right? Journal of Accounting Research 42 (3): 561-588.

35. Knechel, W. R., P. Rouse, \& C. Schelleman. (2009). A modified audit production framework: Evaluating the relative efficiency of audit engagements. The Accounting Review 84 (5): 1607-1638.

36. Kothari, S. P., A. J. Leone, \& C. E. Wasley. (2005). Performance matched discretionary accrual measures. Journal of Accounting and Economics 39 (1):163-197.

37. Krishnan, G.V. (2003). Does Big 6 auditor industry expertise constrain earnings management? Accounting Horizons (supplement): 1-16.

38. Lawrence, A., M. Minutti-Meza, \& P. Zhang. (2011). Can Big 4 versus non-Big 4 differences in auditquality proxies be attributed to client characteristics? The Accounting Review 86 (1): 259-286.

39. Lennox, C. (1999). Are large auditors more accurate than small auditors? Accounting and Business Research 29 (3): 217-227.

40. Li, C. (2009). Does client importance affect auditor independence at the office level? Empirical evidence from going-concern opinions. Contemporary Accounting Research 26 (1): 201-230.

41. Lu, T., \& H. Sapra. (2009). Auditor conservatism and investment efficiency. The Accounting Review 84 (6): 1933-1958. 
42. McGahan, A. M., \& M. E. Porter. (2002). What do we know about variance in accounting profitability? Management Science 48 (7): 834-851.

43. Nelson, M., \& H. Tan. (2005). Judgment and decision making research auditing: A task, person, and interpersonal interaction perspective. Auditing: A Journal of Practice \& Theory 24 (Supplement): 41-71.

44. Nelson, M., J. Elliott, \& R. Tarpley. (2002). Evidence from auditors about managers' and auditors' earnings management decisions. The Accounting Review 77 (Supplement): 175-202.

45. Palmrose, Z-V. (1988). An analysis of auditor litigation and audit service quality. The Accounting Review 63(1): 55-73.

46. Palmrose, Z-V., \& S. Scholz. (2004). The circumstances and legal consequences of non-GAAP reporting: Evidence from restatements. Contemporary Accounting Research 21 (1): 139-180.

47. Pittman, J., \& S. Fortin. (2004). The impact of auditor's reputation on the cost of financing. Journal of Accounting and Economics 37 (1): 113-136.

48. Plumlee, M., \& T. L. Yohn. (2010). An analysis of the underlying cause attributed to restatements. Accounting Horizon 24 (1): 41-64.

49. Prawitt, D., J. L. Simth, \& D. A. Wood. (2009). Internal audit quality and earnings management. The Accounting Review 84 (4): 1255-1280.

50. Reichelt, J.K., \& D.Wang. (2010). National and office-specific measures of auditor industry expertise and effects on audit quality. Journal of Accounting and Economics 30 (3): 375-400.

51. Reynolds, J.D., \& J. Francis. (2000). Does size matter? The influence of large clients on office-level auditor reporting decisions. Journal of Accounting and Economics 33 (3): 375-400.

52. Teoh, S., \& T. J. Wong. (1993). Perceived auditor quality and the earnings response coefficient. The Accounting Review 68 (2): 346-366.

53. Wang, Y., L. Yu, Z. Zhang, \& Y. Zhao. (2012). Engaging audit partner experience and audit quality. AAA conference, Washington D.C.

54. Wallman, S. M. H. (1996). The future of accounting, part three: Reliability and auditor independence. Accounting Horizons 10 (December): 76-97.

55. Vuong, Q. H. (1989). Likelihood ratio tests for model selection and non-nested hypotheses. Econometrical: Journal of the Econometric Society 57 (2): 307-333. 
NOTES 